\title{
Ancient Egyptians in Black and White: 'Exodus: Gods and Kings' and the Hamitic Hypothesis
}

\author{
Justin Michael Reed
}

Citation: Reed, Justin Michael. 2021. Ancient Egyptians in Black and White: 'Exodus: Gods and Kings' and the Hamitic Hypothesis. Religions 12: 712. https://doi.org/10.3390/ rel12090712

Academic Editor: Joel Baden

Received: 16 July 2021

Accepted: 25 August 2021

Published: 2 September 2021

Publisher's Note: MDPI stays neutral with regard to jurisdictional claims in published maps and institutional affiliations.

Copyright: (C) 2021 by the author. Licensee MDPI, Basel, Switzerland. This article is an open access article distributed under the terms and conditions of the Creative Commons Attribution (CC BY) license (https:// creativecommons.org/licenses/by/ $4.0 /)$
Department of Biblical Studies, Louisville Presbyterian Theological Seminary, Louisville, KY 40205, USA; jreed@lpts.edu

\begin{abstract}
In this essay, I consider how the racial politics of Ridley Scott's whitewashing of ancient Egypt in Exodus: Gods and Kings intersects with the Hamitic Hypothesis, a racial theory that asserts Black people's inherent inferiority to other races and that civilization is the unique possession of the White race. First, I outline the historical development of the Hamitic Hypothesis. Then, I highlight instances in which some of the most respected White intellectuals from the late-seventeenth through the mid-twentieth century deploy the hypothesis in assertions that the ancient Egyptians were a race of dark-skinned Caucasians. By focusing on this detail, I demonstrate that prominent White scholars' arguments in favor of their racial kinship with ancient Egyptians were frequently burdened with the insecure admission that these ancient Egyptian Caucasians sometimes resembled Negroes in certain respects-most frequently noted being skin color. In the concluding section of this essay, I use Scott's film to point out that the success of the Hamitic Hypothesis in its racial discourse has transformed a racial perception of the ancient Egyptian from a dark-skinned Caucasian into a White person with appearance akin to Northern European White people.
\end{abstract}

Keywords: Ham; Hamite; Egyptian; Caucasian; race; Genesis 9; Ridley Scott; Charles Copher; Samuel George Morton; James Henry Breasted

\section{Introduction}

Every so often, Hollywood puts together another costly, mythic-historical epic to dazzle viewers. ${ }^{1}$ During the twenty-first century, the commercial success of some films within this broader genre has contributed to Hollywood funding a number of popular productions specifically based upon the Bible, ${ }^{2}$ ancient Egypt, ${ }^{3}$ or both ${ }^{4}$ (Elliott 2014; Burnette-Bletsch and Morgan 2017, pp. 1-2). Whenever I learn about a forthcoming film on the Bible or ancient Egypt, my initial desire is to interrogate the ways in which the casting intersects with a history of racializing discourses and their consequences in the United States. (Of course, if I eventually watch the film, then the plot, costume, framing, and more deserve critique as well). While I was researching the reception history of Noah's curse (Genesis 9:18-29) in order to situate Darren Aronofsky's Noah (2014) within a broader history of racialized depictions of Ham (Reed 2017), a friend turned my attention toward another film - a potentially more controversial example of racist biblical reception-being released in the same year: Ridley Scott's Exodus: Gods and Kings (2014).

Prior to its release, Scott's film was frequently criticized for its continuation in a long history of Hollywood portraying ancient Egypt in the image of White ${ }^{5}$ people. When confronted about his decisions and alerted to threats of the movie being boycotted, Scott provided some questionable responses. In one of his most quoted and criticized answers, Scott says, "I can't mount a film of this budget [ ... ] and say my lead actor is Mohammad so-and-so from such-and-such" (Foundas 2014). In another statement, Scott speaks with much more tact: "Egypt was-as it is now - a confluence of cultures, as a result of being a crossroads geographically between Africa, the Middle East, and Europe. We cast major actors from different ethnicities to reflect this diversity of culture, from Iranians to Spaniards 
to Arabs. There are many different theories about the ethnicity of the Egyptian people, and we had a lot of discussions about how best to represent the culture" (Yahoo Movies Australia 2014). Ultimately, Scott's reference to the diversity of ancient Egypt did not assuage public concerns because the issue was more than just the inclusion of diversity in his film. While the casting of White people to play ancient Africans and Southwest Asians has become a frustrating norm for Hollywood films, Okaka Opio Dokotum asserts that audiences were most enraged by Scott's decision to cast Africans to play only the roles of mute and exotic servants, lower class civilians, a thief, and an assassin swiftly killed by Moses (Dokotum 2020, pp. 226-27). These combined elements-a prominent White ruling class over an ancient African civilization served by a largely insignificant Black caste-project the same metanarrative that has been used as ideological support for Western colonialism and the enslavement of African people. It is a construction of reality that scholars call the Hamitic Hypothesis or Hamitic Myth.

In this essay, I will reflect on Scott's film in dialogue with this racist legacy. In the abovementioned book by Dokotom, the author dedicates one chapter to considering the impact of cyber-activism incited by Scott's casting. Dokotum focuses on audiences' reception and reaction to the casting and how it instigated the hashtag \#BoycottExodusMovie, which successfully drew people together to hurt Ridley Scott's box office performance (Dokotum 2020, pp. 225-30). In an edited volume on Scott's film, other scholars have already explored different issues aside from the casting controversy, such as the politics of gender representation and the depiction of God in the film (Tollerton 2017a). In the introduction to that work, David C. Tollerton acknowledges that the accusation of racist casting is one of the primary issues that has drawn attention to the film, but he avoids any sustained engagement with the racial politics of Exodus (2014) and instead references several online pieces written for popular audiences (Lilly 2015; Edwards 2014; Canning 2014; Tollerton 2017b). Among these works, the brief CNN.com article by Joel Baden and Candida Moss comes closest to my essay. Baden and Moss critique the ways in which Scott's film does more than simply miss the opportunity to cast a more historically accurate or racially sensitive ensemble; Scott's film actually supplies visual imagery that would be embraced by nineteenth-century slavery apologists (Baden and Moss 2014). This essay delves deeper into the topic of seeing Scott's film in dialogue with a history of contentious racial discourse in the United States.

The outline of the essay contains three main parts. First, I define the Hamitic Hypothesis by considering the historical trajectory of its development from ideas in the Hebrew Bible that had not yet congealed into a racial theory into the two main articulations of the Hamitic Hypothesis that coincide with European enslavement of African people and imperial domination of various indigenous groups into the nineteenth century. In this section, I add the twentieth-century experiences of biblical scholar Charles Copher (19132003) to demonstrate the endurance of the Hamitic Hypothesis after American slavery had been abolished. Beyond the end of Copher's scholarship in the 1990s, I consider the ways that the Hamitic Hypothesis has continued to challenge biblical scholarship in the twenty-first century. In the next section, I take a closer look at the ways in which some of the most respected White intellectuals in several disciplines have deployed racial (il)logics in the Hamitic Hypothesis to describe the ruling White race in Egypt as dark-skinned Caucasians. ${ }^{6}$ By focusing on this detail, I highlight what is missing from the analysis of Baden and Moss as well as many other scholars: prominent White intellectuals' arguments in favor of their racial kinship with ancient Egyptians were frequently burdened with the insecure admission that these ancient Egyptian Caucasians sometimes resembled Negroes in certain respects-most frequently noted being skin color. In the concluding section of this essay, I return to Scott's film with this strain of the Hamitic Hypothesis in mind. I point out that the success of the Hamitic Hypothesis in accomplishing the primary goal of its White adherents—showing a shared racial identity with ancient Egyptians—-has generated a racial perception of the ancient Egyptians as thoroughly Caucasian in appearance akin to Northern European White people. 


\section{What Is the Hamitic Hypothesis?}

Scholars have used the term "Hamitic Hypothesis" to describe one overarching worldview - that civilization is antithetical to the Black race and uniquely consonant with the White race-expounded in two related but distinct racial theories that are now discredited. In Edith R. Sanders' oft-referenced article on the topic, she explains that, chronologically, the first concept of the Hamitic Hypothesis describes a theory where people are racialized as Negro and Hamites for a large period of history and the second is one where people are racialized as Caucasian and Hamites during a later period of history. In both cases, the nomenclature derives from the biblical story of Noah and his three sons, Shem, Ham, and Japheth. Yet the function of identification with Ham entails opposite consequences in the "Negro-Hamite" concept vs. the "Cacasoid-Hamite" concept (Sanders 1969). In order to grasp the differences, it is helpful to consider the relevant biblical texts and how they are weaponized against Black people in each concept.

In one of the most popular stories from the Hebrew Bible, Noah survives the flood along with his wife, three sons, and their wives (Genesis 6-9). As the story of Noah's life draws to a close, readers are privy to one final event with a very disturbing history of consequences. After God's rainbow covenant with Noah, Genesis 9:18-29 narrates a story in which Noah becomes drunk and disrobes; then, one of Noah's sons, Ham, sees his father's nakedness. After Ham tells his two brothers, Shem and Japheth, they cover Noah without seeing his nakedness. The plot climaxes with Noah cursing Canaan-Ham's son and his own grandson-as a "slave of slaves" 'ebed 'ăbadîm) and proclaiming that Canaan will serve Shem and Japheth. Although the text reads that Noah literally curses Canaan, interpreters have used various details within the text in a long history of reading Ham as cursed by God (Reed 2020, pp. 130-32). With this passage as the central focus, identification with Ham entails a cursed, servile, and degenerate state of being.

Many Jewish, Christian, and Muslim sources have identified Black people with Ham because the biblical text describes all the earth as peopled by Noah's three sons (Genesis 9:19), and Ham's sons are the eponymous ancestors of African peoples in Kush, Egypt, and Punt (Genesis 10:6). This identification was strengthened when readers as far back as the third century began to associate the biblical name, "Ham" (ham) and the color hwm with the root hmm, "to be hot," with the implication that Ham is the ancestor of people who are dark-skinned like an object that is burned or blackened by heat (Goldenberg 2003, pp. 144-56). However, it would be a mistake to consider the identification of African people with Ham as self-evident or consistent across history. Popular depictions of Ham over the centuries include seeing him as the forefather of Jews, Muslims, Asians, religious heretics, sinners, sodomites, monstrous creatures (with a horse head or two heads or leprechauns), Native Americans, serfs, and European royalty in addition to Ham representing Black people and Africans (Allen 1963, p. 120; Braude 1997, pp. 120-21, 133, 138-40; Braude 2005, p. 81; Freedman 1999, pp. 89, 94, 97-100; Goldenberg 2017, pp. 33-41, 174-83; Kaplan 2019, pp. 1-18, 103-34; Whitford 2009, pp. 39-42, 70). As Benjamin Braude notes, "the racial identities the sons [of Noah] have borne have been remarkably unstable" (Braude 1997, p. 142). Furthermore, the cases in which Ham is associated with Africa did not automatically entail associating African people or blackness with a cursed state of being. In fact, a survey of biblical texts dealing with Africans shows that many authors of the Hebrew Bible associated African nations such as Kush and Egypt with military might, political stability, wealth, and human wisdom (Bailey 1991). Early post-biblical Jewish sources continued to mention Black people without engrained negative evaluations (Goldenberg 2003, pp. 46-75). In other words, the biblical text did not necessitate the Black-Hamite version of the Hamitic Hypothesis for readers.

Changing historical circumstances precipitated a shift in the discourse. Whereas some early sources did note dark-skinned people in connection with slavery, scholars point out that the times when different cultures engaged in a dramatic increase in the enslavement of Black people correlate with an increase in interpreting Ham (or Canaan) as Black in order to justify or explain this enslavement (Evans 1980; Goldenberg 2003, pp. 174-75). ${ }^{7}$ In the case 
of Muslims, conquests in Africa around the mid-seventh century generated this increase (Goldenberg 2017, pp. 87-104); for Christians the exponential increase of Black enslavement by Europeans in the sixteenth century was the catalyst (Goldenberg 2017, pp. 105-45).

In two appendices to his monograph Black and Slave, David Goldenberg includes more than 100 quotations of authors from the eighteenth century to the twentieth century in Europe and the United States engaging in discourse on the association between contemporary Black people and Ham (or Canaan) (Goldenberg 2017, pp. 207-37). Jonathan Schorsch lists more than forty sources from 1400-1700 that fit the same category (Schorsch 2004, pp. 135-38). Many of these writers use the connection between Ham and contemporary Black people to explain the enslavement and subjugation of Black people that they see, others aim to justify continuing that enslavement, and still others are writing to refute the explanations and justifications that they claim are widespread among their contemporaries. Henry William Martin typifies the use of the Black-Hamite hypothesis to justify Black enslavement when, in refuting William Wilberforce's assertion that slavery in the West Indies is unjust, he begins, "First, that slavery was not unjust in its origin, and is not unjust in its continuance, nor displeasing to God." He then supports his thesis by quoting Genesis 9:25-27 and adding, "This prophetical curse is still fulfilling in the descendants of Ham and Canaan" (Martin 1823, pp. 2-3). In the context of the United States, Josiah Priest's widely read Slavery, as It Relates to the Negro is one of the more famous uses of the Black-Hamite hypothesis to justify slavery (Priest 1843). The use of Noah's curse to rationalize enslavement of Black people became so common that Theodore Dwight Weld commented, the "prophecy of Noah is the vade mecum of slaveholders, and they never venture abroad without it [ ... ]" (Weld 1838, p. 46); and Alexander Crummell called it a "general, almost universal, opinion in the Christian world [ ... ] found in books written by learned men; and it is repeated in lectures, speeches, sermons, and common conversation" (Crummell 1853, pp. 3-4). In this iteration of the Hamitic Hypothesis, Black people are Hamites, distinguishable by their physical features and their divinely sanctioned, eternal servile character. As with the overarching idea of the Hamitic Hypothesis, Black people as Hamites are inherently uncivilized and in need of domination by the master White race.

Even while this version of the Hamitic Hypothesis continued to influence thought well into the twentieth century (Goldenberg 2003, pp. 142-43; Goldenberg 2017, pp. 23537; Reed 2020, pp. 40-43), another version of the Hamitic Hypothesis developed in which White people are described as Hamites. According to Sanders, a shift to the Caucasoid-Hamite concept in European thought can largely be attributed to the influence of Enlightenment philosophy in raising scientific reasoning and natural observation to epistemological prominence over theological reasoning through appeals to scripture (Sanders 1969, p. 523). This shift in method continued the trend of the Negro-Hamite concept in justifying slavery by asserting Black people's inherent inferiority and even went further in questioning their full humanity. Although Sanders attributes the WhiteHamite concept to science rather than scripture, many of its main proponents welcomed the fact that it generated the same conclusion as the previous concept with regard to Blacks. Furthermore, many pro-slavery Christians integrated these scientific theories into their interpretations of the Bible such that Negroes-if they are not from Ham-are unmentioned in the Bible, a race created before Adam, or even beasts in God's natural economy (Fredrickson 1972, pp. 71-96).

The appeal to science could have operated alongside identification of Black people as a Hamitic race, but questions raised by Napoleon's 1798 invasion of Egypt complicated the issue. Prior to Napoleon's expedition, some observers in ancient and modern times (such as Herodotus and Volney mentioned below) had commented on the ancient Egyptians as being a race of Black people and highly civilized, but these voices were not the center of attention when ethnologists described the degenerate state of the Black race. However, when Napoleon brought scientists on his expedition, they sparked a sustained interest in Egypt that would make the issue of ancient Egyptians' race unavoidable (Sanders 1969, pp. 524-25; Copher 1993, pp. 22-24). One of Napoleon's accompanying observers 
and artists, Dominique Vivant, Baron Denon (1747-1825), described the Copts (whom he considered to be the most direct, although mixed, ancestors of the ancient Egyptians) as people with dark skin and facial features akin to how his contemporaries describe Negroes (Denon 1803a, vol. 1, pp. 206-7). Furthermore, Denon produced a sketch of the Sphinx about which he wrote, "the character is African, but the mouth, the lips of which are thick, has the softness and delicacy of execution truly admirable" (Denon 1803b). Remarks like these implied that Western civilization owed its greatness to the genius of an ancient Black race.

White people's responses to the growing interest in Egypt varied. In associating Egyptians with Africa, some scholars argued that they were the opposite of the prevailing value of progress: "Egypt represented an earlier, lower and strangely dead stage of human evolution which had been raised by the European genius of Hellas [Greece] to a qualitatively higher level" (Bernal 1987, vol. 1, p. 214). Later this prejudice was replaced by depictions of ancient Egyptians as childlike: "gay, pleasure-loving, childishly boastful and essentially materialistic" (Bernal 1987, vol. 1, pp. 30, 265). The solution that I would like to focus on involves the reaction to transform the Hamitic Hypothesis. While still using the language of Genesis 10:6 to group ancient Egyptians with other descendants of the biblical Ham, scholars transitioned to arguing that these Hamites were White. Thus, the great civilization of Egypt (and any later achievements that were discovered in Africa) could be attributed to White people (whether autochthonous or invaders), and the ideological underpinnings for White domination through enslavement and imperialism could remain secure since civilization remained the unique property of the White race (Burrell 2020, pp. 47-52).

While the above historical development of the White-Hamite version of the Hamitic Hypothesis shows the importance of material interests in slavery and colonialism to its general acceptance, Robin Law adds that African people-through their own interests and prior traditions - contributed to its construction. Europeans did not simply invent a diffusionary model to convince Africans of the foreign origins of their civilizations; many African people were already describing themselves as descended from biblical Hamites prior to contact with European versions of the Hamitic Hypothesis. These Africans knew of biblical traditions due to earlier Muslim influences, and had adopted diffusionary origin stories that fit their own agendas (Law 2009, pp. 298-306). The Fulani, for example, claimed that they were "white," which in their own context "denoted (patrilineal) Arab descent and free status, rather than skin color;" and this self-designation informed Europeans rather than reflecting a simple acceptance of European prejudices (Law 2009, pp. 305-6). Thus, the White-Hamite version of the Hamitic Hypothesis became a standard racial theory across the many contexts of Africa, Europe, and the Americas.

In the United States, the Hamitic Hypothesis influenced the development of several academic disciplines and impacted the general public as well. Charles Copher, often treated as one of the founders of African American biblical studies (Bailey 2000, pp. 69798; Brown 2004, pp. 25-34; Reid 2008, pp. 485-87; Smith 2017, pp. 26-27), describes the profound influence of the Hamitic Hypothesis on his intellectual development. In a somewhat autobiographical journal article, Charles Copher reviews his own life trajectory as it intersects with his major academic interest in recovering the Black presence in the Bible and the ancient world (Copher 1995). As Copher explains, his early academic development was heavily influenced by the racist writings that served as the official scholarship of his day. According to Copher, at the age of 10, he read two books on ancient history in which Phillip Van Ness Myers (1846-1937) claimed that the Black race lived south of the Sahara and had been slaves to stronger races since time immemorial (Myers 1898, pp. 2, 7; Myers 1904, pp. 15, 19). Copher adds, "These flagrant assertions concerning the servile, inferior character of Blacks made an indelible impression upon me" (Copher 1995, p. 4). In a context in which Copher could look to his grandparents' marks from the enslavers' whips, and where he knew of others in his community who experienced slavery, Myers' racist narrative of history would have a profound grip on Cophers' young mind. 
When Copher attended high school, James Henry Breasted's (1865-1935) textbooks, Ancient Times and The Conquest of Civilization, were the standard. In them, Copher read that "the Great White Race" created all civilization, including those in the valley of the Nile, and the "Negro peoples of Africa were therefore without any influence in the development of early civilization" (Breasted 1935, p. 133; Breasted 1938, p. 44; Copher 1995, pp. 5-7). As Copher makes clear, iterations of the Hamitic Hypothesis (or more specifically, what he called the "New Hamitic Hypothesis") like those found in the works of Myers and Breasted "were representative of the historical studies that I pursued throughout my years in high school, college, seminary, and even graduate school" (Copher 1995, p. 7). Copher's experience was far from unique; the textbooks written by Myers and Breasted were some of the most widely read by high school and college students in the United States (The Cincinnati Enquirer 1937; Ambridge 2012, pp. 19-20). Furthermore, as Lindsay J. Ambridge makes clear in her essay contextualizing Breasted's Ancient Times, the integration of the Hamitic Hypothesis into their writing was far from incidental. In its correlation to Breasted's stance on imperialism and resource exploitation, this racialized reading was an essential element of the entire historical project (Ambridge 2012).

Copher describes himself as "indoctrinated" by these white supremacist beliefs. The consequences included an elevated valuation of whiteness-a desire to be integrated into, accepted by, and applauded within White society. It was not until the 1968-1969 academic year (two decades after earning his $\mathrm{PhD}$ ) that student protests-fueled by the assassination of Martin Luther King, Jr., and the beliefs of the Black Power Movement-catalyzed a shift in Copher's perspective (Copher 1995, pp. 8-9). As Copher was "re-born" into a new embrace of his own Black identity, he began his studies on Black people in the ancient world and the Bible in order to assemble critical and objective proof to overturn the racist metanarratives that had plagued his academic development. Copher's publications on this subject began in the 1970s and carried on into the early 1990s (cf. Copher 1993, 1991).

In biblical studies, Copher's scholarship has been the main source of publications directly addressing and aiming to attenuate the power of the White-Hamite myth in the minds of Bible readers. In the decades since Copher began to pioneer Black biblical interpretation, new voices have emerged that continue his goals of countering racist metanarratives engrained in biblical studies and popular culture. However, the many African American, African, Afro-diasporic, and non-Black scholars who have carried on this task in the twenty-first century tend to accept an African presence in the Bible and to generate scholarship beyond Copher's method of uncovering the Black presence. Newer methods include analyzing how Africans are depicted in religious texts (Byron 2002); paying attention to issues of gender, class, and sexuality in biblical texts as well as the contexts of writers and readers (Bailey 2009, 2010; Byron and Lovelace 2016; Gafney 2017); interrogating the liberatory potential of biblical texts for marginalized people (Bennett 2003; Masenya 2005; Weems 2003); and studying the psychological, social, cultural, and political meanings of scripture for Africana peoples (Bowens 2020; Love 2013; Junior 2020; Junior and Schipper 2020; Marbury 2015; Powery and Sadler 2016; Schipper 2017; Wimbush 2000). Thus, Copher's more narrow focus on deconstructing the Hamitic Hypothesis by demonstrating the Black presence in the Bible is no longer a central aim of Africana biblical interpretation.

It is true that a few biblical scholars in the twenty-first century explicitly refer to the influence of some version of the Hamitic Hypothesis and the need for continued scholarship to challenge it. Edwin Yamauchi, for example, notes the consequences of the White-Hamite concept on African people, including its role in ongoing enmity between Tutsi and Hutu people in Rwanda (Yamauchi 2004, pp. 29-30, 206-7). Although he does not use the term "Hamitic Hypothesis," J. Daniel Hays describes the influence of both versions on biblical studies in old publications that are still in print as well as cases in which scholars insert their prejudiced assumption of Black slavery into texts that simply mention Kushites (Hays 2007, pp. 316-17, 322-26). At times, Rodney Sadler does come close to Copher's method when he attempts to expand reader's appreciation for the African context and 
characters in the New Testament (Sadler 2007). In other works, Sadler demonstrates how the anti-Black racial prejudices engrained in the Hamitic Hypothesis (and other areas of modern thought) are absent from the Hebrew Bible's rhetoric concerning the Kushites (Sadler 2005, 2006). Most recently, Kevin Burrell charts the historical development of the Hamitic Hypothesis when he examines the evolution of racial ideas in Western history as a background to understand the lacunae and inaccuracies in scholarship on Kushite and Egyptian history (Burrell 2020, pp. 25-59). Even though there are important parallels between the two, Burrell's work diverges in important ways from Copher's search for the Black presence in the Bible.

The main difference between Copher and Burrell is the latter's reticence to foreground race in relationship to ancient people and the biblical text. Like Copher, Burrell clearly understands the importance of racial theories that have supplied the ideological support for Western domination around the world (Burrell 2020, pp. 25-59). In fact, he begins his book by noting the importance of race, epistemology, and historiography for highly contentious modern issues (Burrell 2020, pp. 1-4). Yet, when he turns to the Hebrew Bible and the ancient historical contexts surrounding the Bible, he does not focus on race. Instead, Burrell, like many other scholars in biblical studies (Sparks 1998; Johnson 2011; Rainey 2018), theorizes on the ways in which ethnicity supplies a better foundation for theories of group identity and othering in the biblical text and the ancient world. ${ }^{8}$ When Burrell does feel pressed to spend a few pages discussing what he refers to as the "thorny issue of physiognomy and skin colour" (Burrell 2020, pp. 80-86), he exhibits caution in emphasizing that any racial categorization in ancient contexts is a modern imposition of racial ideas that are specific and relevant in completely foreign modern contexts. Consequently, Burrell's main point that he shares with many scholars (especially Stuart Tyson Smith and Bruce Trigger, whom he cites often) is that biological evidence and primary sources from ancient Egypt show that they and their Kushite neighbors shared similar physical characteristics that would relegate an Egyptian and Kushite to the back of the bus if they took a hypothetical trip to the segregated Jim Crow South (Burrell 2020, p. 82). In other words, Burrell will call ancient Egyptians (and Kushites) Black in reference to how race functions in a specific time and context; and he does it based on ancient and modern evidence but not the testimony of the Bible.

Michael Joseph Brown's 2004 introduction to African American biblical scholarship demonstrates some of the reasons why Copher's focus on proving race from the Bible has not been adopted wholeheartedly by Burrell and other twenty-first-century biblical scholars who note the dangers of the Hamitic Hypothesis. Brown analyzes two essays by Copher, the first of which is not an attempt to show the Black presence in the Bible and the ancient world. Instead that essay is a general reception history of biblical texts as they relate to Black people (Copher 1989). Although he applauds Copher's judicious arguments that unmask Eurocentric deficiencies in interpretation, Brown's "most serious question" for this essay is about whether there is any real foundation for African Americans-whose African ancestry derives largely from sub-Saharan Africa-to see themselves in the biblical text when Black people from Northeast Africa (Egypt and Kush) are mentioned (Brown 2004, pp. 28-29). In other words, Copher's essay does not theorize racial classification in a way that makes a convincing connection between the modern African American reader and biblical subjects. As noted above, Burrell and others diverge from Copher by including more sophisticated theorization about groupness, which leads to the frequent use of ethnicity rather than race as the subject for engagement.

In the other essay that Brown discusses, Copher does note some of the major difficulties with theorizing about race. He points out the problem of how racial classification has been "confused and contradictory" in the United States (Copher 1991, pp. 146-47). The solution Copher supplies here (and explains in more detail elsewhere) is to assert his own agency over epistemologies that had previously been leveraged by White researchers against Black people. Copher takes contemporary methods meant to exclude Black people from the benefits protected for Whites and applies those same methods to the biblical text in order 
to include Black people in the annals of history: he defines the Black race by using White people's focus on dark skin color, putatively distinctive Negro physical features, any trace of such appearance, any known Negro ancestry, or even one drop of Negro blood (Copher 1995, pp. 25-26). By applying these modern racial categories and distinctions that he knows are anachronistic, Copher racializes a host of biblical characters as Black and directly counters the White-Hamite concept that all (or almost all) of the characters in the Bible are White. When considering how Copher uses this reasoning to argue that Mesopotamians were Black, Brown points out a substantial problem in how Copher's delineation of race influences his results: "From a different perspective, however, such racial classification is misleading at best" (Brown 2004, p. 31). However, Brown's biggest problem with Copher's essay is that "Copher makes a mistake common to historical critics of the Hebrew Bible: He accepts the biblical narrative on its face and uses it as the basis for writing history" (Brown 2004, pp. 32-34). Although Copher is well aware of this issue with excessive confidence in the historicity of the biblical witness (Copher 1993, pp. 47-49), it does not deter him from drawing conclusions about Black historical figures from the Bible. Sadler, Burrell, and other scholars that look at the biblical text in relation to issues of race tend to show more caution in looking at the biblical text as a record of Israelite and Judean thought and looking to other sources to establish history.

A decade after Brown's book, Ron Hendel adopts Brown's critiques of Copher during an argument against postmodern ideological criticism of the Bible, but Hendel seems to miss the underlying issue of the Hamitic Hypothesis. Hendel quotes Brown's statements: "this argument [that Moses and his family were Black] is far from historically convincing" and "serious questions of method and proof (independent or otherwise) lie behind any such attempt to make historically valid ethnic claims" (Hendel 2014, p. 434; Brown 2004, pp. 32,34). Although Hendel accurately quotes Brown's critique, he leaves out the nuances of Brown's conclusion. Brown concludes his assessment of Copher's lack of historical evidence by conceding the overall accuracy of Copher's description of the biblical texts:

Returning to Copher's conclusion, we must say that the claim that the ancient Israelites were black is based on a particular reading and appropriation of the Hebrew Bible. As it stands, there is little or no verifiable connection between the literary forms and world of the Hebrew Bible and the historical one to which a claim such as this by necessity refers. Copher is correct when he says that in the various narratives, poems, and prophesies of the Old Testament there is an incredible amount of mixing between Israelites and Africans, specifically Egyptians and Ethiopians. And although the real historical questions surrounding this literature are in dispute, Copher's arguments are undeniably correct with respect to the biblical story (Brown 2004, p. 34).

In other words, Brown concludes that Copher's particular reading of the Hebrew Bible does counteract the White-Hamite hypothesis at the level of the biblical story even though it proves nothing about history. According to Brown, it would not, as Hendel conjectures, "be just as untenable to claim that Moses and his family were white Aryans or Hasidic Jews" (Hendel 2014, p. 433) because-even though these claims might also lack any proof of their historical accuracy - it is not a foregone conclusion that such assertions would have the same level of evidence within biblical texts.

Hendel also deserves critique here because his citation of Nazi German arguments for an Aryan Jesus as examples of problematic ethno-racial exegesis analogous to Copher's (Hendel 2014, pp. 433-34; Heschel 2008) shows a blind spot regarding the pervasiveness of the White-Hamite concept much closer to home. Although the writings of a Third Reich group aiming to show how Nazis can hate Jews and love Jesus might be summarily discounted by a twenty-first-century reader because of its obvious connotations as white supremacist, Copher's writing was not directed at critiquing foreign ideologies or fringe ideas. As illustrated above, Copher worked to counteract mainstream scholarship embraced in the United States-works that he was taught were standards in his academic career. This includes works like a popular commentary on Genesis by John Skinner (1851- 
1925) (which Hendel would easily recognize considering his many publications on Genesis since the 1980s) and an essay by William Foxwell Albright (1891-1971) (the famous Doktorvater of Hendel's famous Doktorvater, Frank Moore Cross (1921-2012)) (Copher 1995, pp. 12-13; Skinner 1910, p. 192; Albright 1952, pp. 238-39). By asserting his opposition to white supremacist exegesis (Hendel 2014, p. 433) but also keeping references to such work at a "safe" distance, Hendel does not take note of the impact of the Hamitic Hypothesis on mainstream scholarship. The legacies of the Hamitic Hypothesis are not as distant in time or space as some might think.

In fact, the White-Hamite version of the Hamitic Hypothesis can even be found in a recent work with the laudable aim of encouraging appreciation for Africans in the Bible. In 2019, Tim Welch, who served as a missionary in Côte d'Ivoire for more than three decades, translated and revised his earlier (2001) publication L'Afrique et les Africains dans la Bible, a book intending to show that Africans are central to much of the story of the Bible and, therefore, the Bible and Christianity cannot be understood as "the white man's" scripture or religion. In his introductory chapter, Welch concludes that the ancient Egyptians and Kushites "can legitimately be called African." Even though he asserts "'African' is not synonymous with 'black,'" the Egyptians' geographical presence and strains of "black African roots" are enough to justify this belief (Welch 2019, pp. 6-7). In route to arriving at this conclusion, Welch quotes language from the French Nouveau dictionaire biblique révisé that expresses the explicitly racialized version of the White-Hamite concept: "In prehistoric times, Ham's descendants of the white race moved into Egypt in successive waves and supplanted the natives" (Pache 1992, p. 384; Welch 2019, p. 3). In contrast to his critique of the logical deficiencies in many Afrocentric claims (Welch 2019, pp. 2-3), Welch presents no contextualization of this idea as it relates to Flinders Petrie's (1853-1942) currently discounted "Dynastic Race Theory" (Burrell 2020, p. 52), no interrogation of its historical context in supporting White people's interests, nor a deconstruction of its racist (il)logic. Welch simply proceeds to accept this as one scholarly explanation in competition with others and shows how scholars agree on the presence of mixing in early Egyptian history.

Although Africans and Africa in the Bible was not written by a scholar with a PhD in biblical studies, Welch's book is endorsed by respected biblical scholars such as Edwin Yamauchi (mentioned above) and M. Daniel Carroll R., who wrote the forward. Welch's citation of the Hamitic Hypothesis as a valid theory with its explicit racial language does not implicate these other scholars as if they harbor the same views. As already noted, Yamauchi (whom Welch cites extensively) briefly describes and critiques the apparent racism of the White-Hamite version of the Hamitic Hypothesis (Yamauchi 2004, pp. 29, 206; Yamauchi 2009, pp. 56-57). However, the fact that Welch's book was written for the purpose of celebrating Africans in the Bible and that it has the approval of bona fide biblical scholars means that this work is not one readers can easily dismiss as fringe scholarship. Consequently, biblical studies continues to be an area in which the Hamitic Hypothesis presents a challenge two decades into the twenty-first century.

In bringing the discussion back to Ridley Scott's film, there are several internet articles that note the issue of race with some historical context in mind (Dennis 2014; Desta 2014; Larsen 2015a, 2015b). Among such works for popular audiences, Joel Baden and Candida Moss, two biblical scholars, dedicate the most space to contextualizing the film in terms of the Hamitic Hypothesis (though they do not use this label). As Baden and Moss make clear, the Antebellum claim that ancient Egyptians were White people solved the incongruity of slavery apologists claiming that Black people were inherently inferior and ancient Egypt was a great civilization. In short, the problem with Scott's movie is that "the tableau produced in 'Exodus,' unfortunately, is the one favored by 19th-century slave traders" (Baden and Moss 2014). In other words, what makes this film so problematic is that it supplies twenty-first-century visual imagery to continue to normalize the White-Hamite version of the Hamitic Hypothesis. 


\section{Dark-Skinned Caucasians in the Hamitic Hypothesis}

Although Baden's and Moss' critiques are helpful, there is one detail from the WhiteHamite version of the theory that deserves further exploration, especially in terms of its relationship to Scott's film. Proponents of the Hamitic Hypothesis frequently made their arguments in favor of Caucasian ancient Egyptians while at the same time conceding that these Caucasians looked in certain regards-most notably skin color-like Black people. From the earliest examples of racial science before this version of the Hamitic Hypothesis became the standard, through the nineteenth-century publications most famous for claiming White Hamites, and into the twentieth-century works that reproduce these racial theories, one can see examples from some of the most well-respected scholars in their fields sharing this seemingly hypocritical assertion that ancient Egyptians specifically, or Hamites more generally, were dark-skinned Caucasians.

Consider, for example, Francois Bernier (1620-1688), whom many scholars regard as the first person to use race in the modern sense of the term (Baum 2006, p. 52)-that is, as "a major division of humanity displaying a distinctive combination of physical traits transmitted through a line of descent" (Bernasconi and Lott 2000, p. viii). In his 1684 publication, he does not label the race as "White" or "Caucasian," but his first racial group collects such disparate people as contemporary Egyptians, Indians, and Europeans. Furthermore, he does so while at the same time admitting that some of "the Egyptians [ ... ] and the Indians are very black, or rather copper coloured [ ... ]" (Bernier 2000, pp. 1-2). Bernier attempts to justify such a designation by rationalizing that the darker skin color of some Egyptians and Indians is not natural to them, but rather the result of constant exposure to the sun (Bernier 2000, p. 2). (At the early stages in the history of racial sciences applied to human diversity, it became common to assert the mutability of physical variations while asserting the influence of climate or other factors.) According to Bruce Baum, Bernier's most distinctive criteria for grouping people into his first race appears to have been "a Eurocentric aesthetic of 'beauty' or 'handsomeness' and the presence or absence of the accoutrements of 'civilization' as Europeans understood them" (Baum 2006, p. 55). In other words, the importance of recognizing civilization as the unique possession of the White race was one of the key factors influencing Bernier to racialize people with "very black, or rather copper coloured" skin, like Indians and Egyptians, alongside Europeans.

Another scholar worth noting for his claims about ancient dark-skinned Caucasians is Samuel George Morton (1799-1851), known as the father figure of the American school of ethnology and often cited for his influence on the Hamitic Hypothesis (Sanders 1969, pp. 527-28; Trafton 2004, p. 17; Baden and Moss 2014). Morton built upon Johann Friedrich Blumenbach's (1752-1840) emphasis on skull measurements as a more accurate indicator of racial distinction than other factors like skin color (although he diverged radically from Blumenbach's belief in the mutability of physical features and the full humanity of Black people). By charting different measurements of his large collection of human skulls, Morton set up patterns for dividing the races with a patina of scientific credibility. In Morton's Crania Americana (Morton 1839) and Crania Aegyptiaca (Morton 1844), he-like his contemporaries-theorized about United States identity through the lens of racial discourse about ancient Egypt. One of the key aims of ethnology was to show that the Black race was naturally and eternally unfit for equality with Whites, so that White people could govern the world in accordance with nature (Trafton 2004, p. 17).

Like many of his predecessors, Morton was certain that the ancient Egyptians must have been a Caucasian race. Noting that other writers have seen the Copts as the closest contemporary group in appearance to the ancient Egyptians, Morton cautions against drawing too close of conclusions from observing the Copts because this "Nilotic" branch of the Caucasian race degenerated on account of mixing with those that conquered them-Persians, Greeks, Romans, Arabians, and Turks-leaving the present people as "the degenerate remains, both physically and intellectually, of that mighty people who have claimed the admiration of all ages" (Morton 1839, p. 25). Morton also reproduces the theory that 
contemporary Nubians of a "brown or reddish brown" or even "a copper color" best represent ancient Egyptians. Although Morton concedes this might be true about some ancient Egyptians, he argues that it is not the case for all (Morton 1844, pp. 28, 57-59). Furthermore, he describes Nubians' appearance with constant qualification about its difference from Negroes. "His face is rather dark, though far removed from African blackness [... ] The hair of the Nubian is thick and black, often curled either by nature or by art, and sometimes partially frizzled, but never woolly." Morton adds that ancient Nubian art shows that "the ancient Nubians, like the modern, were in no respect analogous to the Negroes, excepting in the occasional blackness of their skin." Finally, Morton insists that ancient Nubians are distinct from the Negroes whom they triumphed over (Morton 1839, p. 26). With these repeated appeals to the Nubian distinction from Negroes, Morton's claims of Caucasian-Nubian identity smack of an anxiety that simple divulging of the physical evidence would lead any rational reader to conclude that the Nubians-with their dark faces, thick curled or frizzy hair, and occasional slipping into the blackness of Negroes-are, in fact, a Negro race of people.

When Morton turns his attention from contemporary people to specifically consider ancient Egyptian complexion, he describes them as like "Hindoos" (Indians) in many ways including that their skin color appears "to have been swarthy or brown, with a tinge of red," and they also possessed a variety of complexions in correlation to class "from nearly white to a very dark brown, even black" (Morton 1839, pp. 28, 32; 1844, p. 29). Through these references to Caucasian Nubians and ancient Egyptians as occasionally matching Negroes in their blackness, Morton holds onto the idea that civilization is uniquely Caucasian even though some of these civilized Caucasians are "black."

As noted in reference to Napoleon's invasion of Egypt, the physical evidence of people and monuments could lead one to argue the converse of Morton's conclusions. Well aware of detractors, Morton included a special note to dispel the suspicions of any observer who might interpret the ancient Egyptian as a Negro. He describes such a deduction as "a vulgar error which has found support in the superficial observations of some men, and the misplaced benevolence of others" (Morton 1839, p. 29). In this section, Morton seeks to discount assertions by African American contemporaries whom he will not name (such as Frederick Douglass (1817-1895), James Theodore Holly (1829-1911), and Henry Highland Garnet (1815-1882)) as well as ancient and relatively contemporary Europeans whose writings suggest, or assert, ancient Egyptians were Black. Morton begins with a critique of French scholar and traveler Constantin-François Chasseboeuf, Comte de Volney (1747-1825), whose observations based upon looking at modern Egyptians and ancient monuments have been frequently quoted. Like Morton, Volney believed that the conquest of ancient Egyptians by others ("the Persians, the Macedonians, the Romans, the Greeks, the Arabs, the Georgians, and [ ... ] the Ottoman Turks") meant that contemporary Egyptians exhibited mixed features (Volney 1788, vol. 1, p. 74). Unlike Morton, Volney asserts that the mixing resulted in the Copts - the people he says most closely relate to the ancient Egyptians - having a "yellowish, dusky complexion [ ... ] a puffed visage, swollen eyes, flat noses, and thick lips, in short the exact countenance of a Mulatto" (Volney 1788, vol. 1, p. 80). In other words, Volney concludes that the intermixture of other people (all from the north) lightened the skin of ancient Egypt's descendants, even while they retained other features that distinguish the Black race. These observations lead Volney to produce his most famous quote:

How are we astonished when we behold the present barbarism and ignorance of the Copts, descended from the profound genius of the Egyptians, and brilliant imagination of the Greeks; when we reflect that to the race of negroes, at present our slaves, and the objects of our extreme contempt, we owe our arts, sciences, and even our very use of speech; and when we recollect that, in the midst of those nations that call themselves the friends of liberty and humanity, the most barbarous of slaveries is justified; and that it is even a problem whether the 
understanding of negroes be of the same species with that of white men! (Volney 1788, vol. 1, pp. 82-83).

Morton disregards Volney's assertions that the ancient Egyptians were Negroes as rooted in Volney's hasty observations of the Sphinx. Instead of demonstrating that the Sphinx is not Negro, Morton points out that Egyptians have been like many peoples throughout history (including Buddhists, Greeks, and Romans) who have borrowed their myths and gods from others. In this case, Egyptians borrowed from their southern neighbors (Morton 1839, p. 27). Elsewhere, Morton comes to the same conclusion as Volney about a large proportion of Copts being a mix of Negro and Caucasian ancestry (Morton 1844, pp. 17, 55-57).

Morton continues his aside by countering a description from the ancient historian Herodotus (fifth century BCE), who comments that the fact that Colchians look "black and have hair short and curling" lends credence to the theory that they descended from Sesostris' Egyptian troops (2.104). Morton avers that Greeks could have described anyone darker than themselves as "black" or that "real Negroes" may have been part of Sesostris' army as members of the "servile or Negro caste in Egypt, and not of the Egyptian race" (Morton 1839, p. 27). Morton elaborates on this point in his Crania Aegyptiaca (Morton 1844), where he comes to the conclusion that "Negroes were numerous in Egypt, but their social position in ancient times was the same that it now is, that of servants and slaves" (Morton 1844, p. 66). With such words, Morton emphasizes the ideological interest of cataloging the races of ancient Egypt as support for the modern institution of race-based slavery. However, Morton must qualify this statement earlier in his book. He notes that Negroes in ancient Egypt sometimes were able to elevate in class as servants-especially as eunuchs — and that intermarriage between Caucasian Egyptians and Negro slaves sometimes produced Negro offspring who inherited the privileges of their Caucasian parent (Morton 1844, p. 60). Again, the efforts to constrain the facts of history into the concise germ of the Hamitic Hypothesis - that Black people are inherently inferior and civilization is uniquely Whitecould not be securely grasped by Morton without exception. Morton felt unable to ignore the fact that some "real Negroes" (as judged by his measurements of skulls and analysis of art) had apparently ascended from their lowly state in Egypt in spite of the fact that race generally can be trusted to predict an eternal nature and place limits on advancement.

In one of his final paragraphs on the subject, Morton quotes George Curvier to emphasize the truth of his claim about Egyptians as Caucasian. According to Curvier,

[no race of Negroes] produced the celebrated people who gave birth to the civilization of ancient Egypt, and of whom we may say that the whole world has inherited the principles of its laws, sciences, and perhaps also religion. It is easy to prove, that whatever may have been the hue of their skin, they belonged to the same race with ourselves. I have examined in Paris, and in the various collections of Europe, more than fifty heads of mummies, and not one amongst them presented the characters of the Negro or Hottentot (Morton 1839, p. 31).

With emphasis, Morton, the father of American ethnology, seems to thinly veil his anxiety about skin color by insisting that the Caucasian identity of ancient Egyptians-their shared racial essence with the European inheritors of their civilizing influence-is not contingent upon (and cannot be disqualified based upon) complexion. An expert like Curvier or Morton will assure any dilettante who thinks otherwise that skulls are what determines race; and the skulls of ancient Egyptians indicate their White race.

With the transition from the nineteenth to the twentieth century, the Hamitic Hypothesis became more entrenched. Other scholars built upon Morton's writings, and, with the help of Josiah Clark Nott (1804-1873) and George Robins Gliddon (1809-1857), the emerging field of Egyptology adopted and refined the White-Hamite concept (Gliddon and Nott 1854). By 1879, Jean Louis Armand de Quatrefages (1810-1892) could comment on the irony of dark-skinned Caucasians while still accepting this racialization as a fact. He writes, "Amongst the Whites there are entire populations, whose skin is as black as that of the darkest Negro" (de Quatrefages 1879, p. 48). For example, he describes the 
Bishareen, a contemporary Egyptian tribe of people, as having "even a darker hue than the true Negro," and later he notes that he finds it inconceivable that the ancient Egyptian looked any different from these dark Egyptians of his day (de Quatrefages 1879, pp. 50, 257). Thus, by the close of the nineteenth century, the Hamitic Hypothesis had established a well-respected racial (il)logic capable of circumventing its own admitted anxieties that the ancient Egyptians' skin color (or other features) should lead them to be classified with other dark-skinned Africans rather than Europeans.

In Black Folk: Then and Now (Du Bois [1939] 2007), W. E. B. Du Bois (1868-1963) perfectly summarizes how the particular strain of the Hamitic Hypothesis that described Hamites as dark-skinned White people had become accepted as fact in the early twentieth century: "Africa had no history. Wherever there was history in Africa or civilization, it was of white origin; and the fact that it was civilization proved that it was white. If black Pharaohs sat on the throne of Egypt they were not really black men but dark white men" (Du Bois [1939] 2007, p. 159). Although Du Bois writes these words to mock a belief that he considers to be an example of historiography in service to economic interests, the language of his parody matches well with the twentieth-century proponents of the Hamitic Hypothesis. For example, Charles Gabriel Seligman (1873-1940), considered the founding father of the London School of Economics Anthropology Department, presented what would become the most notorious articulation of the Hamitic Hypothesis in his extremely popular Races of Africa first published (1930) and then revised (1939) in the same decade as Du Bois' comments. According to Seligman:

[... ] the civilizations of Africa are the civilizations of the Hamites, its history the record of these peoples and of their interactions with the two more primitive African stocks, the Negro and the Bushman, whether this influence was exerted by highly civilized Egyptians or by such wilder pastoralists as are represented at the present day by the Beja and the Somali. [ ... ] The Hamites [ . . ] are Caucasian, i.e., belong to the same great branch of mankind as almost all Europeans [ ... ] (Seligman 1930, pp. 96-97).

In describing the Eastern Hamites (whom he equates with the ancient and modern Egyptians) as Caucasian, Seligman repeatedly insists that their physical characteristics should not lead us to think that they are Negroes - at least not originally. If they have any features resembling a true Negro, then Seligman must indicate its non-Negro distinction or hypothesize its origin through mixing. Their face "apart from Negro admixture is never prognathous; [ ... ] their lips are often thick but never everted as in the Negro, [ ... ] the colour of the skin varies, it may be yellowish, coppery, reddish-brown through every shade of café-au-lait to black, according to the amount of miscegenation that has taken place" (Seligman 1930, pp. 97-98). As with Morton, Seligman's argument about White Hamites depends upon ways he can disregard physical features that they share with Black people.

Other highly influential twentieth-century scholars adopt the concept of dark-skinned Caucasian Hamites without attempts to rationalize these features like Seligman and his forerunners. James Henry Breasted's abovementioned textbook Ancient Times introduces "the Great White Race" as the people who, following the glacial recession that ended the Ice Age, "inhabited the whole Northwest Quadrant, where eventually was produced the civilization which is ours today." In establishing this direct racial link between the ancient progenitors of civilization and his implied White audience, Breasted adds, "In North Africa these people were dark-skinned, but nevertheless physically they belong to the Great White Race" (Breasted 1935, pp. 12, 130). In a section titled "The Quarter of the Globe Where Civilization Grew Up and Developed," Breasted repeatedly emphasizes this connection between ancients and the modern White people of Europe and the United States who have inherited civilization from them (Breasted 1935, pp. 129,131). Rather than summarize the arguments of racial sciences on why skull shape shows White people of various complexions belong to the same race (as Morton and others had done), Breasted actually uses skull shape to show the diversity of the White race! In Figure 80, Breasted contrasts drawings of an ancient Egyptian skull with one from "an Ancient Highland Zone 
Man" and asserts, "The people of the Great White Race differ markedly in certain physical characteristics. Scientists have found, for example, that there is a striking variation in the shape of the skull" (Breasted 1935, p. 131). Thus, Ambridge argues,

'White,' in Breasted's formulation, was less a construct of skin color and more a construct of achievement and control. The populations that comprised Breasted's Great White Race could have a variety of skin colors and physical features; the common denominator was their achievement $[\ldots$. . ] He constructed a narrative of human history in which the advancement of societies [ ... ] was given order by imposing a unity upon the bearers of this progress. That unity was the Great White Race (Ambridge 2012, pp. 29-30).

In other words, the White-Hamite concept seems to have gained such approval that Breasted has no qualms about using the evidence of craniology-which Curvier and Morton emphasized as showing Egyptian's kinship with Europeans-to show ancient Egyptians' difference from other White people.

One of the most influential scholars in twentieth-century biblical studies and biblical archeology, William Foxwell Albright, also racializes ancient North Africans as darkskinned Caucasians. In an article on "The Old Testament World" in The Interpreters Bible, adjoining pages penned by Albright state that, on the one hand, ancient Egyptians have the same reddish-brown skin color as many modern Egyptians and, on the other hand, these Egyptians and "all known ancient races in the region that concern us here belonged to the so called 'white' or 'Caucasian' race, with the exception of the Cushites ('Ethiopian') who were strongly Negroid in type, as we know from many Egyptian paintings" (Albright 1952, pp. 238-39).

In these twentieth-century examples from Breasted and Albright, one can see a continuation of the racial discourse about dark-skinned White Hamites; however, these sources are not like the writings of Bernier, Morton, or Seligman, who each attempt to explain how these dark-skinned Caucasians differ from potentially similar dark-skinned Negroes. In part, this is the nature of their works. Bernier, Morton, and Seligman were writing about human variation and needed to establish theories from their data; Breasted and Albright were mentioning races in works on the history of human civilization and the context of the Old Testament, respectively. However, another reason for the difference might have to do with the fact that the idea of the White Hamite had thoroughly taken root. Since the Hamitic Hypothesis was common knowledge, Breasted and Albright could simply assert the congruity between whiteness and civilization without further citation or argument.

\section{Conclusions}

As critical race theorists have thoroughly demonstrated, race is a social construct, which entails that the process of constructing race (racialization) has varied in its particular details across time and space as well as in its application to different groups (Harris 1993). This brief foray into one strain of the racialization involved in the Caucasian version of the Hamitic Hypothesis exemplifies this point about the social construction of race. To conclude this paper, I adopt a framework from Matthew Frye Jacobson's Whiteness of a Different Color as a way to place the racializing discourse of the White-Hamite concept in dialogue with three elements of the racial politics of casting in Exodus: Gods and Kings (2014): "race as an organizer of power whose vicissitudes track power relationships through time; race as a mode of perception contingent upon the circumstances of the moment; and race as the product of specific struggles for power at specific cultural sites" (Jacobson 1998, p. 11).

The two elements involving power can be discussed first. As I have asserted above, the Hamitic Hypothesis is a racial theory that organizes humanity in specific reference to power relationships and has transformed in response to the vicissitudes of historical circumstances that might threaten to deconstruct its persuasiveness. With an identification of Black people as cursed Hamites, race has functioned to denigrate Blacks under Whites. However, the potential of identifying an ancient civilization like Egypt as Black led to a new 
configuration of White people as civilized Hamites. In the course of these changes over time, racialization steadily functions to justify White people's social, political, and economic power. Furthermore, the way that this racial discourse organizes relationships of power functions quite independently of the flesh-and-blood Egyptians being racialized. Neither past centuries' assertions that ancient (or modern) Egyptians are dark-skinned Caucasians nor contemporary debates around Scott's film function to leverage actual benefits for real Egyptians. Indicative of this point-although by a slightly removed analogy-is the 1923 case of United States v. Bhagat Singh Thind. In this case, Thind was not Egyptian but Indian, another group often considered by scientists to be included in the White race regardless of skin color or other features. Although scholars in 1923 would consider Aryan ethnicity (which Thind possessed) as a feature of the White race, the Supreme Court ruled that Thind was not White according to common knowledge and, therefore, not worthy of citizenship, which was a privilege reserved for White people (Jacobson 1998, p. 236). The court acknowledged his whiteness according to ethnology, but not in a way that could gain him material benefits because the court had the power, at that moment, to ensure that the established racial discourse was not put to use in leveraging power for the party it was never engineered to support.

Control over the discourse continues to be an issue of power. The arguments concerning Egyptians (or even Indians) as Caucasian in racial sciences emerged from the specific cultural struggle to uphold or deconstruct ideological supports for white supremacy. At its core, debates about the race of ancient Egyptians are one arena (among many) in which Black people attempt to destabilize White people's hegemony over epistemologies (and White people attempt to maintain this hegemony). In the case of the United States before the Civil Rights Movement, the clear material circumstances intertwined with these debates included Jim Crow, slavery, and other forms of state-sanctioned violence that was often coupled with explicitly articulated language about Black inferiority or White superiority. In the case of Exodus: Gods and Kings (2014), the contemporary cultural context of that year included the widespread protests and organizing by the Black Lives Matter (BLM) movement. The attention generated around police killings of Eric Garner (1970-2014), John Crawford III (1992-2014), Michael Brown (1996-2014), Tamir Rice (2002-2014), and many others galvanized people to declare that "Black Lives Matter" in the face of evidence to the contrary. Not only has there been resistance to the BLM movement, but there has also been resistance to affirming the statement itself. These protests and counter-protests formed the cultural background to the critiques of racist casting in the Exodus movie. When Ridley Scott coarsely dismissed calls to boycott his film, ${ }^{9}$ his comments added fuel to the fire of many people (not just Black people) incensed with White hegemonic control over racializing narratives. Thus, the racial imagery presented in the film and the response in the \#BoycottExodusMovie campaign can be understood as cultural struggles over the power to present racial discourses, and its historical concurrence with 2014-2015 BLM protests likely resulted in greater intensity in this contention against the film.

Finally, transitioning from the two elements of power to the element of perception, I conclude by commenting on the anxiety with affirming ancient Egyptians as dark-skinned White people and its connection to Scott's film. As already noted, a major insecurity motivating the scholarship concerning dark-skinned Caucasians was the fact that this presumably natural racial perception seemed to have eluded-or held the ever-present potential to elude-audiences. As Trafton notes, regardless of the lack of explicit documentary evidence to prove the case, one can see that "early American Egyptologists certainly believed that the proposal of a 'supposed affinity between the Egyptians and Negroes' was an organized and insistent threat" (Trafton 2004, p. 56). Even without naming them, these White writers were responding to the published claims of ancient and modern opponents, including Black intellectuals who exposed the insecurities in Whites' racializing project with quips like the following from Holly: "Let them prove by the subtlest refinement of reasoning that those ancient darkies were pure white men" (Holly 1859, p. 186; Trafton 2004, p. 63). As an outgrowth of this anxiety that a wider culture indoctrinated with equat- 
ing dark skin with the Black race would believe-and had believed-Egyptians are Black, White scholars attempted to inculcate a deeply engrained notion of ancient Egyptians as definitively White in spite of appearances otherwise.

One can see that this change in perception has been thoroughly accomplished for some people, as evinced by the casting of Scott's Exodus: Gods and Kings (2014), and most pointedly in the defense of this casting on Twitter by the former chairman and CEO of 21st Century Fox, Rupert Murdoch: "Since when are Egyptians not white? All I know are" (Rawlinson 2014). After receiving negative responses, Murdoch continues, "Everybody attacks last tweet. Of course Egyptians are Middle Eastern but far from black. They treated blacks as slaves" (Rawlinson 2014). Without interrogating the important issues of historical population migrations and the politics of racial nomenclature that would be important for claims about modern Egyptian racial classification Murdoch seems to point to in the first tweet, we can at least state the following: Murdoch has followed the tradition of the Hamitic Hypothesis in defining ancient Egyptian racial identity as White through insistence on negating its connection to Blacks and, with Blacks, slavery. Furthermore, with the issue of racial perception, the dark complexion that caused so much anxiety and need of explanation for previous audiences has disappeared completely in the eyes of Murdoch (and those who share his view). As Jacobson astutely notes, people are conditioned by practices and traditions to see race in ways that are variable from one racializing context to another (Jacobson 1998, pp. 9-10). The idea that one could see an ancient Egyptian as a "real Negro" is what Morton would call "a vulgar error" in need of correction by an expert who knows better; by the time of Scott's twenty-first-century film, Murdoch had become so thoroughly trained by traditions to believe in the unqualified veracity of a White ancient Egypt that he cannot perceive that such an "error" would even happen.

Funding: This research received no external funding.

Conflicts of Interest: The author declares no conflict of interest.

\section{Notes}

$1 \quad$ Thanks are due to many people who read or listened to earlier presentations of this research and generously provided constructive criticism: Lawrence Anglin, Meghan Alexander Beddingfield, David Carr, Isabel Cranz, Vanessa Davies, Catherine Howard, Brian Rainey, Matodzi Gift Ramashia, and the people at Myrtle Baptist Church in West Newton, MA.

2 Some of the most popular examples include Mel Gibson's The Passion of the Christ (2004); Roma Downey and Mark Burnett's The Bible (2013) miniseries on the History Channel, and its adaptation by Christopher Spencer into the film Son of God (2014); Darren Aronofsky's Noah (2014); and Kevin Reynold's Risen (2016).

3 Some of the most popular examples include Stephen Sommers' The Mummy Returns (2001); Chuck Russell's The Scorpion King (2002); and Alex Proyas' Gods of Egypt (2016). Patty Jenkins' Cleopatra is still in production but might deserve inclusion in this list in the near future.

$4 \quad$ Ridley Scott's Exodus: Gods and Kings (2014).

5 I capitalize "White" and "Black" as racial descriptors of people, but for different reasons. Like Latino, Asian, and other ethnoracial terms, Black deserves capitalization in the ways that it functions to demarcate an ethnic, racial, or cultural identity. Aside from vocal proponents of white supremacy, today's White people do not profess an analogous sense of shared "White" ethnic, racial, or cultural identity. However, this general posturing of whiteness as neutral or invisible contributes to the maintenance of power and privilege for White people. Therefore, I capitalize "White" to highlight the fact that—in spite of perceptions of its neutrality-it functions as a racialized identity.

6 I prefer to use the terms "Black" and "White" as racial terms rather than the more dated and potentially offensive "Negro" and "Caucasian." However, I occasionally shift to these antiquated labels when quoting or referencing scholarship that uses these terms.

7 Adding further specificity to this claim, Benjamin Braude argues that the precise moment of increased acceptance of the curse of Ham (or Canaan) as justification for Black enslavement happened in each culture when they could blame some other group for this degrading interpretation: Muslims blamed Jewish sources and Christians blamed Muslim (and even Hindu) sources (Braude 2002, pp. 124-25; Braude 2003, pp. 50-63).

8 As Katherine Southwood explains, "Despite the conceptual and analytical similarities between the three concepts [ethnicity, nationalism, and race], the discredited, pseudo-scientific application of the term 'race', which suggests the existence of insurmountable ontological and biological differences, makes it an illigimate concept to work with" (Southwood 2012, p. 41). 
To those who protest his movie because of its racist casting, Scott wrote, "Get a life" (BigStory.AP.Org 2014).

\section{References}

Albright, William Foxwell. 1952. The Old Testament World. In The Interpreters Bible. Edited by George A. Buttrick. New York: Abingdon Press, vol. 1, pp. 233-71.

Allen, Don Cameron. 1963. The Legend of Noah: Renaissance Rationalism in Art, Science, and Letters. Urbana: University of Illinois Press. Ambridge, Lindsay J. 2012. Imperialism and Racial Geography in James Henry Breasted's Ancient Times, a History of the Early World. Journal of Egyptian History 5: 12-33. [CrossRef]

Baden, Joel, and Candida Moss. 2014. Does the New 'Exodus' Movie Whitewash the Bible? CNN.Com, December 11. Available online: http:/ / www.cnn.com/2014/12/10/showbiz/exodus-whitewash-bible/ (accessed on 3 March 2015).

Bailey, Randall C. 1991. Beyond Identification: The Use of Africans in Old Testament Poetry and Narratives. In Stony the Road We Trod. Edited by Cain Hope Felder. Minneapolis: Fortress Press, pp. 165-86.

Bailey, Randall C. 2000. Academic Biblical Interpretation among African Americans in the United States. In African Americans and the Bible. Edited by Vincent L. Wimbush. New York: Continuum, pp. 696-711.

Bailey, Randall C. 2009. 'That's Why They Didn't Call the Book Hadassah!' The Interse(ct)/(x)ionality of Race/Ethnicity, Gender, and Sexuality in the Book of Esther. In They Were All Together in One Place? Toward Minority Biblical Criticism. Edited by Randall C. Bailey, Tat-Siong Benny Liew and Fernando F. Segovia. Semeia Studies 57. Atlanta: SBL, pp. 227-50.

Bailey, Randall C. 2010. Why Do Readers Believe Lot? Genesis 19 Reconsidered. Old Testament Essays 23: 519-48.

Baum, Bruce. 2006. The Rise and Fall of the Caucasian Race: A Political History of Racial Identity. New York: New York University Press.

Bennett, Harold V. 2003. Yet with a Steady Beat: Contemporary U.S. Afrocentric Biblical Interpretation. Edited by Randall C. Bailey. Semeia Studies 42. Leiden: Brill, pp. 7-18.

Bernal, Martin. 1987. Black Athena: The Afroasiatic Roots of Classical Civilization. 3 vols. New Brunswick: Rutgers University Press, vol. 1.

Bernasconi, Robert, and Thomas L. Lott. 2000. Introduction. In The Idea of Race. Edited by Robert Bernasconi and Thomas L. Lott. Indianapolis: Hackett.

Bernier, Francois. 2000. A New Division of the Earth. In Idea of Race. Edited by Robert Bernasconi and Thomas L. Lott. Indianapolis: Hackett, pp. 1-2.

BigStory.AP.Org. 2014. Scott, Bale Defend 'Exodus' Casting. December 8. Available online: http://bigstory.ap.org/article/29866a953d0 34ab891d2fd87a79ff54b / scott-bale-defend-choice-exodus-casting (accessed on 3 March 2015).

Bowens, Lisa M. 2020. African American Readings of Paul: Reception, Resistance, and Transformation. Grand Rapids: Eerdmans Publishing Company.

Braude, Benjamin. 1997. The Sons of Noah and the Construction of Ethnic and Geographic Identities in the Medieval and Early Modern Periods. The William and Mary Quarterly 54: 103-42. [CrossRef]

Braude, Benjamin. 2002. Cham et Noé: Race, esclavage et exégèse entre islam, judaïsme et christianisme. Annales. Histoire, Sciences Sociales 57e: 93-125. [CrossRef]

Braude, Benjamin. 2003. Ham and Noah: Sexuality, Servitudinism, and Ethnicity. Paper presented at the Fifth Annual Gilder Lehrman Center International Conference at Yale University, Yale University, New Haven, CT, USA, November 7. Available online: https://glc.yale.edu/sites/default/files/files/events/race/Braude.pdf (accessed on 20 April 2018).

Braude, Benjamin. 2005. Michelangelo and the Curse of Ham: From a Typology of Jew Hatred to a Genealogy of Racism. In Writing Race Across the Atlantic World, 1492-1789. Edited by Philip D. Beidler and Gary Taylor. New York: Palgrave Macmillan, pp. 79-92.

Breasted, James Henry. 1935. Ancient Times: A History of the Early World, 2nd ed. Boston: Ginn and Company.

Breasted, James Henry. 1938. The Conquest of Civilzation... Including New Text, the Author's Own Revisions and Notes. Edited by Edith Williams Ware. New York: Harper \& Brothers.

Brown, Michael Joseph. 2004. Blackening of the Bible: The Aims of African American Biblical Scholarship. Harrisburg: Trinity Press International.

Burnette-Bletsch, Rhonda, and Jon Morgan, eds. 2017. Noah as Antihero: Darren Aronofsky's Cinematic Deluge. New York: Routledge.

Burrell, Kevin. 2020. Cushites in the Hebrew Bible: Negotiating Ethnic Identity in the Past and Present. Brill Interpretation Series 181; Leiden: Brill.

Byron, Gay L. 2002. Symbolic Blackness and Ethnic Difference in Early Christian Literature. London: Routledge.

Byron, Gay L., and Vanessa Lovelace, eds. 2016. Womanist Interpretations of the Bible: Expanding the Discourse. Atlanta: SBL Press.

Canning, Charlotte M. 2014. Ridley Scott's Casting of White Actors Is Symptomatic of Larger Problems. TheConversation.Com. December 17. Available online: https://theconversation.com/ridley-scotts-casting-of-white-actors-is-symptomatic-of-larger-problems35527 (accessed on 1 March 2015).

Copher, Charles B. 1989. Three Thousand Years of Biblical Interpretation with Reference to Black Peoples. In African American Religious Studies: An Interdisciplinary Anthology. Edited by Gayraud Wilmore. Durham: Duke University Press, pp. 105-28.

Copher, Charles B. 1991. The Black Presence in the Old Testament. In Stony the Road We Trod: African Americans and Biblical Interpretation. Edited by Cain Hope Felder. Minneapolis: Fortress Press, pp. 146-64.

Copher, Charles B. 1993. Black Biblical Studies: An Anthology of Charles B. Copher. Chicago: Black Light Fellowship.

Copher, Charles B. 1995. Blacks/Negroes: Participants in the Development of the Ancient World and Their Presence in the Bible. Journal of the I.T.C. 23: 3-47. 
Crummell, Alexander. 1853. The Negro Race Not under a Curse: An Examination of Genesis IX 25. London: Wertheim, Macintosh, \& Hunt. de Quatrefages, Jean Louis Armand. 1879. The Human Species. London: C. Kegan Paul \& Co.

Dennis, David, Jr. 2014. You Probably Shouldn't Go See Ridley Scott's Pretty Racist 'Exodus' Movie. Medium, August 5. Available online: https:/ / davidjdennisjr.medium.com/you-probably-shouldnt-go-see-ridley-scotts-pretty-racist-exodus-movie-37471c4 d7628 (accessed on 23 March 2021).

Denon, Vivant. 1803a. Travels in Upper and Lower Egypt in Company with Several Divisions of the French Army, During the Campaign of General Bonaparte in That Country. Translated by Arthur Aikin. 3 vols. London: T. N. Longman and O. Rees, vol. 1.

Denon, Vivant. 1803b. Account of the Sphinx, Near Cairo: Illustrated by a Profile View. Universal Magazine, September.

Desta, Yohana. 2014. The Whitewashed Cast of 'Exodus' Is Irresponsible-And Its Own Demise. Mashable. December 11. Available online: https: / / mashable.com/2014/12/11/exodus-movie-racist/ (accessed on 23 March 2021).

Dokotum, Okaka Opio. 2020. Hollywood and Africa: Recycling the "Dark Continent" Myth, 1908-2020. South Africa: African Humanities Program.

Du Bois, William Edward Burghardt. 2007. Black Folk: Then and Now. Edited by Henry Louis Gates Jr. Oxford: Oxford University Press. First published 1939.

Edwards, Katie. 2014. The Tantastic Gods and Kings Epic Is Suspect but Well Worth a Watch. The Conversation, December 24. Available online: https:/ / theconversation.com/ exodus-the-tantastic-gods-and-kings-epic-is-suspect-but-well-worth-a-watch35795 (accessed on 9 July 2021).

Elliott, Andrew B. R. 2014. The Return of the Epic Film: Genre, Aesthetic and History in the Twenty-First Century. Edinburgh: Edinburgh University Press.

Evans, William McKee. 1980. From the Land of Canaan to the Land of Guinea: The Strange Odyssey of the 'Sons of Ham'. The American Historical Review 85: 15-43. [CrossRef]

Exodus: Gods and Kings. 2014. Ridley Scott, director. Los Angeles: 20th Century Fox.

Foundas, Scott. 2014. Exodus: Gods and Kings' Director Ridley Scott on Creating His Vision of Moses. Variety.Com, November 25. Available online: http://variety.com/2014/film/news/ridley-scott-exodus-gods-and-kings-christian-bale-1201363668/ (accessed on 3 March 2015).

Fredrickson, George M. 1972. The Black Image in the White Mind: The Debate on Afro-American Character and Destiny, 1817-1914. New York: Harper \& Row.

Freedman, Paul H. 1999. Images of the Medieval Peasant. Stanford: Stanford University Press.

Gafney, Wilda C. 2017. Womanist Midrash: A Reintroduction to the Women of the Torah and the Throne. Louisville: Westminster John Knox Press.

Gliddon, George R., and Josiah Nott. 1854. Types of Mankind: Or, Ethnological Researches Based Upon the Ancient Monuments, Paintings, Sculptures, and Crania of Races, and Upon Their Natural, Geographical, Philological, and Biblical History. Philadelphia: J. B. Lippincott, Grambo \& Co.

Gods of Egypt. 2016. Alex Proyas, director. Santa Monica: Lionsgate.

Goldenberg, David M. 2003. The Curse of Ham: Race and Slavery in Early Judaism, Christianity, and Islam. Princeton: Princeton University Press.

Goldenberg, David M. 2017. Black and Slave: The Origins and History of the Curse of Ham. Berlin: de Gruyter.

Harris, Cheryl I. 1993. Whiteness as Property. Harvard Law Review 106: 1710-91. [CrossRef]

Hays, J. Daniel. 2007. Racial Bias in the Academy ... Still? Perspectives in Religious Studies 34: 315-29.

Hendel, Ron. 2014. Mind the Gap: Modern and Postmodern in Biblical Studies. Journal of Biblical Literature 133: 422-43.

Heschel, Susannah. 2008. The Aryan Jesus: Christian Theologians and the Bible in Nazi Germany. Princeton: Princeton University Press.

Holly, James Theodore. 1859. Thoughts on Hayti. The Anglo-African Magazine 1: 185-7.

Jacobson, Matthew Frye. 1998. Whiteness of a Different Color. Cambridge: Harvard University Press.

Johnson, Willa M. 2011. The Holy Seed Has Been Defiled: The Intermarriage Dilemma in Ezra 9-10. Sheffield: Sheffield Phoenix Press.

Junior, Nyasha, and Jeremy Schipper. 2020. Black Samson: The Untold Story of an American Icon. Oxford: Oxford University Press.

Junior, Nyasha. 2020. The Mark of Cain and White Violence. Journal of Biblical Literature 139: 661-73.

Kaplan, M. Lindsay. 2019. Figuring Racism in Medieval Christianity. New York: Oxford University Press.

Larsen, Andrew E. 2015a. Exodus: What Race Were the Ancient Egyptians? An Historian Goes to the Movies (blog), December 7. Available online: https:/ / aelarsen.wordpress.com/2015/12/06/exodus-what-race-were-the-ancient-egyptians/ (accessed on 23 March 2021).

Larsen, Andrew E. 2015b. Exodus: Gods and Kings: Does It Whitewash? An Historian Goes to the Movies (blog), December 10. Available online: https:/ / aelarsen.wordpress.com/2015/12/09/2337/ (accessed on 23 March 2021).

Law, Robin. 2009. The 'Hamitic Hypothesis' in Indigenous West African Historical Thought. History in Africa 36: 293-314. [CrossRef]

Lilly, Ingrid. 2015. Marching on a Hard Heart: Selma Is the Exodus That Ridley Scott Failed to Deliver. Huffington Post, September 1. Available online: http:/ / www.huffingtonpost.com/ingrid-lilly/marching-on-a-hard-heart-selma-is-the-exodus-that-ridleyscott-failed-to-deliver_b_6437694.html (accessed on 20 December 2015).

Love, Velma E. 2013. Scriptures as Sundials in African American Lives. In MisReading America: Scriptures and Difference. Edited by Vincent L. Wimbush. Oxford: Oxford University Press, pp. 86-116. 
Marbury, Herbert Robinson. 2015. Pillars of Cloud and Fire: The Politics of Exodus in African American Biblical Interpretation. New York: NYU Press.

Martin, Henry William. 1823. A Counter Appeal in Answer to "An Appeal" from William Wilberforce, Esq., M.P., Designed to Prove That the Emancipation of the Negroes in the West Indies, by a Legislative Enactment, Without the Consent of the Planters, Would Be a Flagrant Breach of National Honour, Hostile to the Principles of Religion, Justice, and Humanity, and Highly Injurious to the Planter and to the Slave. London: C. \& J. Rivington.

Masenya, Madipoane J. 2005. An African Methodology for South African Biblical Sciences: Revisitng the Bosadi (Womanhood) Approach. Old Testament Essays 18: 741-51.

Morton, Samuel George. 1839. Crania Americana: Or a Comparative View of the Skulls of Various Aboriginal Nations of North and South America; to Which Is Prefixed an Essay on the Varieties of the Human Species. Philadelphia: J. Dobson.

Morton, Samuel George. 1844. Crania Aegyptiaca, Or Observations on Egyptian Ethnography, Derived from Anatomy, History and the Monuments. Philadelphia: J. Pennington.

Myers, Philip Van Ness. 1898. A General History for Colleges and High Schools. Boston: Ginn and Company.

Myers, Philip Van Ness. 1904. Ancient History. Revised. Boston: Ginn and Company.

Noah. 2014. Darren Aronofsky, director. Los Angeles: Paramount Pictures.

Pache, René, ed. 1992. Egypte. In Nouveau dictionnaire biblique révisé. Saint-Léger: Editions Emmaüs.

Powery, Emerson B., and Rodney Sadler. 2016. The Genesis of Liberation: Biblical Interpretation in the Antebellum Narratives of the Enslaved. Louisville: Westminster John Knox Press.

Priest, Josiah. 1843. Slavery, as It Relates to the Negro, or African Race, Examined in the Light of Circumstances, History and the Holy Scriptures; with an Account of the Origin of the Black Man's Color, Causes of His State of Servitude and Traces of His Character as Well in Ancient as in Modem Times. Edited by Gerald N. Grob. Anti-Movements in America. Albany: C. Van Benthuysen, vol. 1.

Rainey, Brian. 2018. Religion, Ethnicity and Xenophobia in the Bible: A Theoretical, Exegetical and Theological Survey. New York: Routledge.

Rawlinson, Kevin. 2014. Rupert Murdoch Defends Use of White Actors in Exodus: Gods and Kings. TheGuardian.Com, November 30. Available online: https://www.theguardian.com/media/2014/dec/01/rupert-murdoch-white-actors-exodus-gods-kings (accessed on 3 March 2015).

Reed, Justin. 2017. 'How-How Is This Just?!': How Aronofsky and Handel Handle Noah's Curse. In Noah as Antihero: Darren Aronofsky's Cinematic Deluge. Edited by Rhonda Burnette-Bletsch and Jon Morgan. New York: Routledge, pp. 145-60.

Reed, Justin. 2020. Noah's Curse and the Presumption of Canaanite Guilt: A New Reading of Genesis 9:18-29. Ph.D. dissertation, Princeton Theological Seminary, Princeton, NJ, USA.

Reid, Stephen. 2008. The Changing Significance of Race: African-Americans and the Hebrew Bible. Religion Compass 2: 484-98. [CrossRef]

Risen. 2016. Kevin Reynolds, director. Culver City: Sony Pictures.

Sadler, Rodney. 2005. Can a Cushite Change His Skin? An Examination of Race, Ethnicity and Othering in the Hebrew Bible. Journal for the Study of the Old Testament Supplement Series 425; Sheffield: Sheffield Academic Press.

Sadler, Rodney. 2006. Can a Cushite Change His Skin? Cushites, 'Racial Othering,' and the Hebrew Bible. Interpretation 60: 386-403. [CrossRef]

Sadler, Rodney. 2007. The Place and Role of Africa and African Imagery in the Bible. In True to Our Native Land: An African American New Testament Commentary. Edited by Brian K. Blount. Minneapolis: Fortress Press, pp. 23-30.

Sanders, Edith R. 1969. The Hamitic Hypothesis: Its Origin and Functions in Time Perspective. Journal of African History 10: 521-32. [CrossRef]

Schipper, Jeremy. 2017. 'On Such Texts Comment Is Unnecessary': Biblical Interpretation in the Trial of Denmark Vesey. Journal of the American Academy of Religion 85: 1032-49. [CrossRef]

Schorsch, Jonathan. 2004. Jews and Blacks in the Early Modern World. Cambridge: Cambridge University Press.

Seligman, C. G. 1930. Races of Africa. Revised. London: Thornton Butterworth Ltd.

Skinner, John A. 1910. A Critical and Exegetical Commentary on Genesis, 1st ed. The International Critical Commentary. New York: Charles Scribner's Sons.

Smith, Mitzi J. 2017. Insights from African American Interpretation. Reading the Bible in the 21st Century. Minneapolis: Fortress Press. Son of God. 2014. Christopher Spencer, director. Santa Monica: Lightworkers Media.

Southwood, Katherine E. 2012. Ethnicity and the Mixed Marriage Crisis in Ezra 9-10: An Anthropological Approach. Oxford: Oxford University Press.

Sparks, Kenton L. 1998. Ethnicity and Identity in Ancient Israel: Prolegomena to the Study of Ethnic Sentiments and Their Expression in the Hebrew Bible. Winona Lake: Eisenbraus.

The Bible. 2013. Roma Downey, and Mark Burnett, directors. 3-31 March 2013, on History. Los Angeles: 20th Century Fox.

The Cincinnati Enquirer. 1937. Historian Taken by Death. The Cincinnati Enquirer, September 21.

The Mummy Returns. 2001. Stephen Sommers, director. Los Angeles: Universal Pictures.

The Passion of the Christ. 2004. Mel Gibson, director. Los Angeles: Icon Productions.

The Scorpion King. 2002. Chuck Russell, director. Los Angeles: Universal Pictures.

Tollerton, David, ed. 2017a. A New Hollywood Moses: On the Spectacle and Reception of Exodus: Gods and Kings. Biblical Reception 4. London: Bloomsbury T\&T Clark. 
Tollerton, David, ed. 2017b. 'Hmmm... But Loved the Plagues': On Engaging with Ridley Scott's Epic and Its Audiences. In A New Hollywood Moses: On the Spectacle and Reception of Exodus: Gods and Kings. Biblical Reception 4. London: Bloomsbury T\&T Clark, pp. 1-9.

Trafton, Scott. 2004. Egypt Land: Race and Nineteenth-Century American Egyptomania. Durham: Duke University Press.

Volney, Constantin-François. 1788. Travels Through Syria and Egypt, in the Years 1783, 1784, and 1785, 2nd ed. 2 vols. London: C. G. J. and J. Robinson, vol. 1.

Weems, Renita. 2003. Re-Reading for Liberation. In Feminist Interpretation of the Bible. Edited by Silvia Schroer and Sophia Bietenhard. Journal for the Study of the Old Testament Supplement Series 374; London: T. \& T. Clark, pp. 19-32.

Welch, Tim. 2019. Africans and Africa in the Bible: An Ethnic and Geographic Approach. Chicago: Oasis International Publishing.

Weld, Theodore Dwight. 1838. The Bible Against Slavery. New York: American Anti-Slavery Society.

Whitford, David M. 2009. The Curse of Ham in the Early Modern Era: The Bible and the Justifications for Slavery. London: Ashgate.

Wimbush, Vincent L., ed. 2000. African Americans and the Bible: Sacred Texts and Social Textures. New York: Continuum.

Yahoo Movies Australia. 2014. Exclusive: Ridley Scott Q \& A for 'Exodus: Gods and Kings'. Yahoo Movies Australia, August 27. Available online: https: / /au.movies.yahoo.com/on-show / article/-/24819148/exclusive-ridley-scott-q-a-for-exodus-gods-and-kings / (accessed on 3 March 2015).

Yamauchi, Edwin. 2004. Africa and the Bible. Grand Rapids: Baker Academic.

Yamauchi, Edwin. 2009. The Curse of Ham. Criswell Theological Review 6: 45-60. 